\title{
Study of the efficacy of ormeloxifene in abnormal uterine bleeding
}

\author{
Priyanka B. Varwatte ${ }^{1 *}$, Michelle Fonseca ${ }^{2}$
}

\begin{abstract}
${ }^{1}$ Department of Obstetrics and Gynaecology, V. N. Desai Hospital, Santacruz, Mumbai, Maharashtra, India ${ }^{2}$ Department of Obstetrics and Gynaecology, Lokmanya Tilak Municipal General Hospital, Mumbai, Maharashtra, India
\end{abstract}

Received: 28 August 2020

Accepted: 05 October 2020

\section{*Correspondence:}

Dr. Priyanka B Varwatte,

E-mail: Priya139.rao@gmail.com

Copyright: (C) the author(s), publisher and licensee Medip Academy. This is an open-access article distributed under the terms of the Creative Commons Attribution Non-Commercial License, which permits unrestricted non-commercial

\begin{abstract}
Background: Abnormal uterine bleeding (AUB) is a diagnosis that does not apply to menorrhagia only, but also includes (menometrorrhagia) excessively prolonged and frequent bleeding. Ormeloxifene (also known as centchroman) is a selective estrogen receptor modulator. This study was conducted to assess the efficacy, safety and compliance of ormeloxifene in the medical management of AUB.

Methods: This quasi experimental, one group pre and posttest research design study was conducted among 30 participants in a tertiary care institute in a metropolitan city during January 2016 to June 2017. Patients with AUB were administered with ormeloxifene were advised to follow up one monthly for the first three months and then three monthly follow up for 6 months.

Results: The mean age of all the patients was $35.96 \pm 5.62$ years. There was statistically significant difference of mean hemoglobin, mean endometrial thickness and mean pregnancy-associated breast cancer (PABC) score observed between pre-treatment and 3 months and 6 months of post treatment. Mean hemoglobin concentration was increased while mean endometrial thickness and mean PABC score was decreased as the duration of treatment was increased from 3 months to 6 months.

Conclusions: Ormeloxifene is quick acting, effective and appears to be a promising option for the medical management of dysfunctional uterine bleeding. It leads to a significant reduction in menstrual blood loss, a significant rise in hemoglobin concentration and a significant decrease in endometrial thickness with very minimal side effect.
\end{abstract}

Keywords: Dysfunctional uterine bleeding, Ormeloxifene, Pregnancy-associated breast cancer, Hemoglobin, Endometrial thickness

\section{INTRODUCTION}

Abnormal uterine bleeding (AUB) (not otherwise specified) is abnormal genital tract bleeding based in the uterus and found in the absence of clinically detectable, structural or organic pathology or iatrogenic cause. It is the most common menstrual disorder in women of reproductive age and is a diagnosis of exclusion. It usually occurs due to hormonal disturbances: reduced levels of progesterone hormone cause low levels of prostaglandin F2 alpha and that leads to menorrhagia (abnormally heavy flow), increased levels of fibrinolytic enzymes plasminogen activator (TPA) and more fibrinolysis. $^{1}$

AUB (not otherwise specified) is a diagnosis that does not apply to menorrhagia only, but also includes (menometrorrhagia) excessively prolonged and frequent bleeding. It occurs more frequently in anovulatory cycles as compared to ovulatory cycles. ${ }^{2}$

The treatment of AUB varies from nonconventional conservative medical and surgical management to radical surgeries. Among conservative management, hormonal 
steroids like tranxemic acid, progesterone or oral contraceptives and danazol are used. Even though a number of treatment modalities are available for treatment of dysfunctional uterine bleeding (DUB), a reliable drug should meet the requirements like drug should be highly effective, high efficacy, convenient to take, cost effective, with minimal side effects and large safety margin.

Selective estrogen receptor modulators (SERMs) also called as designer estrogens are a class of drugs that act on the estrogen receptor (ER). They selectively bind with high affinity to estrogen receptors in various tissues, but act as estrogen antagonist in others. So, it causes endometrial suppression. ${ }^{3}$ Ormeloxifene (also known as centchroman) is a selective estrogen receptor modulator. ${ }^{4}$ It is widely used oral contraceptive. It acts by high affinity interaction with ER, antagonize the effect of estrogen on uterine and breast tissue and stimulates the effect on vagina, bone, cardiovascular system and central nervous system. ${ }^{5}$ Ormeloxifene was introduced in Delhi in July 1991, marketed in India in 1992 as Saheli and Choice and Centron and was included in the national family welfare program in $1995 .^{6}$

Due to its potent anti-estrogenic and weak estrogenic activities it is also effective against advanced breast cancer. ${ }^{7}$ In the treatment of AUB the standard dosage is $60 \mathrm{mg}$ orally twice weekly for a period of 12 weeks followed by weekly once in the next 12 weeks. The safety level of ormeloxifene is excellent with very few side effects like headache, nausea, weight gain, delayed or prolonged menstrual period.

\section{METHODS}

This quasi experimental, one group pre and posttest research design study was conducted in a tertiary care institute in a metropolitan city during January 2016 - June 2017. Data was collected from women who attended Gynecology OPD or admitted in the hospital. The population for the study comprises of women with AUBin the reproductive age group who were present at the study settings during the study period. Sample size was calculated using the formula of difference between two means considering the mean endometrial thickness pretreatment was $8.55 \pm 2.42 \mathrm{~mm}$ and $3 \mathrm{rd}$ month post treatment was $8.55 \pm 2.42 \mathrm{~mm}$ as per the study conducted by Masand et al calculated minimum sample size was $30 .^{10}$

Women patients with AUB (not otherwise specified) in the reproductive age group (15-45 years) and who were willing to participate in the study were included in the study while women with postmenopausal bleeding, endometrial biopsy suggestive of atypical hyperplasia or malignancy, cervical dysplasia, bleeding dyscrasia, fibroid uterus/adenomyosis/endometrial polyp, clinical evidence of jaundice or hepatic dysfunction, hypersensitivity to the drug, uterine size >6weeks, women desirous of fertility and with heart disease, hypertension, PCOD were excluded from the study. Non probability purposive sampling technique was used for the proposed study. All the patients of AUB (not otherwise specified) in reproductive age group who fulfilled the criteria of inclusion was taken into consideration till the required sample size was achieved.

Informed consent was taken from all patients included in study. In all cases a detailed history regarding age, parity, medical history, symptomatology, menstrual history, etc was taken and systemic and pelvic examination and various lab investigations like $\mathrm{BT}, \mathrm{CT}, \mathrm{CBC}, \mathrm{PT} / \mathrm{INR}$, TSH were done. Ormeloxifene was administered orally in the form of $60 \mathrm{mg}$ tablet twice weekly for first 12 weeks and then once a week for next 12 week. Patients were asked to maintain menstrual calendar. Patient were advised to follow up one monthly for the first three months and then three monthly follow up for 6 months. At each visit, a detailed menstrual history i.e. intervals at which menses came, no. of days of bleeding, no. of pads, size of clots passed, degree of soiling, history of passage of clots and dysmenorrhea were taken and physical examination was done. Menstrual blood loss was measured objectively by a pictorial blood loss assessment chart (PBAC) score. PBAC is a simple and less timeconsuming procedure for objective assessment of menstrual blood loss. A PBAC score $>100$ indicate a menstrual blood loss $>80 \mathrm{ml}$ diagnostic of DUB. All patients were advised to keep a record of their menstrual blood loss including intervals at which menses came, no. of days of bleeding, no of pads, size of clots, passed degree of soiling, history of passage of clots and dysmenorrhea.

Pretreatment baseline cycles were compared with treatment cycles of ormeloxifene. Outcome were compared with base line parameters like $\mathrm{Hb}$, endometrial thickness by TVS, PBAC Scoring measured at start of therapy, at 3 months and after 6months of treatment.

Data was entered in microsoft excel and was analyzed using SPSS version 20.0. The qualitative data was represented in the form of frequency and percentage and the quantitative data in the form of mean and standard deviation. Comparison of mean score before treatment and after treatment was done with repeated measures ANOVA and $\mathrm{p}$ value less than 0.05 was considered as statistically significant.

\section{RESULTS}

The study was conducted among 30 participants. Most of the patients were in 36-40 years group (40.0\%). The mean age of all the patients was $35.96 \pm 5.62$ years with a range of 26-44 years. Maximum number of patients $(70 \%)$ belonged to parity 2 . All the patients had menorrhagia. Most common side medical illness was anemia (Table 1). 
There was statistically significant difference of mean hemoglobin, mean endometrial thickness and mean PABC score observed between pre-treatment and 3 months and 6 months of post treatment. Mean hemoglobin concentration was increased while mean endometrial thickness and mean PABC score was decreased as the duration of treatment was increased from 3 months to 6 months (Table 2).

Table 1: Baseline characteristics of study participants.

\begin{tabular}{|lll|}
\hline Variables & Frequency & Percentage \\
\hline Age group (in years) & & \\
\hline $26-30$ & 7 & 23.33 \\
\hline $31-35$ & 5 & 16.67 \\
\hline $36-40$ & 12 & 40.00 \\
\hline $41-45$ & 6 & 20.00 \\
\hline Parity status & \\
\hline 1 & 2 & 6.67 \\
\hline 2 & 10 & 33.33 \\
\hline 3 & 11 & 36.67 \\
\hline$>3$ & 7 & 23.33 \\
\hline Pre-treatment symptoms & \\
\hline Menorrhagia & 30 & 100.0 \\
\hline Dysmenorrhea & 17 & 56.67 \\
\hline Medical history & & \\
\hline Anemia & 11 & 36.67 \\
\hline Thalassemia trait & 2 & 6.67 \\
\hline Hypothyroidism & 1 & 3.33 \\
\hline SLE & 1 & 3.33 \\
\hline
\end{tabular}

Table 2: Effect of drug on hemoglobin, endometrial thickness and menstrual blood loss after 3 months and 6 months of post treatment.

\begin{tabular}{|c|c|c|c|}
\hline Parameters & Mean & SD & p value \\
\hline \multicolumn{4}{|l|}{ Hemoglobin } \\
\hline Pre-treatment & 9.83 & 2.10 & \multirow{3}{*}{$0.0001 *$} \\
\hline After 3 months & 10.57 & 1.67 & \\
\hline After 6 months & 11.07 & 1.46 & \\
\hline \multicolumn{4}{|c|}{ Endometrial thickness in mm } \\
\hline Pre-treatment & 9.23 & 1.07 & \multirow{3}{*}{$0.0001 *$} \\
\hline After 3 months & 8.30 & 0.98 & \\
\hline After 6 months & 6.53 & 1.38 & \\
\hline \multicolumn{4}{|l|}{ PBAC } \\
\hline Pre-treatment & 201.40 & 30.482 & \multirow{3}{*}{$0.0001 *$} \\
\hline After 3 months & 132.23 & 40.069 & \\
\hline After 6 months & 102.40 & 63.083 & \\
\hline
\end{tabular}

* Significant.

\section{Side-effect}

One case $(3.33 \%)$ developed myocardial infarction when on study drug. Seventy percent of the cases were satisfied on treatment with the drug while $30 \%$ of the patients were not satisfied with the drug. There was marked improvement in 26 cases while 2 cases had no improvement and 2 cases had aggravation of symptoms.

\section{DISCUSSION}

Medical management has always been the first therapeutic option to be tried and if it fails to show results, one can resort to surgical interventions. Medical management of menorrhagia should aim to relieve symptoms, improve quality of life and avoid risk of surgery. This study was done in Obstetrics and Gynecology Department in a tertiary care institute to assess the efficacy, safety and compliance of ormeloxifene in the management of DUB.

The mean hemoglobin level before treatment was $9.83 \pm 2.10 \mathrm{gm} \%$ and it was improved significantly to $10.57 \pm 1.67$ after 3 months and $11.07 \pm 1.46$ after 6 months of treatment with ormeloxifene. Similar results were observed by Agarwal et al most of the women are anemic with $81.67 \%$ women having a hemoglobin level less than $10 \mathrm{gm} \%$. The mean pretreatment hemoglobin was 9.04 gm\% which was improved significantly to $10.01 \%$ at 3 months $(\mathrm{t}=20.38$, $\mathrm{p}$ value $<0.0001)$ and further increased to $10.86 \%$ at 6 months $(\mathrm{t}=34.42$, $\mathrm{p}$ value $<0.0001) .{ }^{11}$ Another study conducted by Gandotra et al observed similar finding of significant rise in mean hemoglobin concentration from $8.4 \mathrm{gm} \%$ to $9.8 \mathrm{gm} \%$ after six months of treatment with a rise of $1.4 \mathrm{gm} \%{ }^{12}$ Study conducted by Masand et al, Biswas et al and Talukdar et al observed similar findings when compared with our study. ${ }^{10,13,14}$

The mean endometrial thickness before treatment was $9.23 \pm 1.07 \mathrm{~mm}$ and it was decreased significantly to $8.30 \pm 0.98 \mathrm{~mm}$ after 3 months and $6.53 \pm 1.38 \mathrm{~mm}$ after 6 months of treatment with ormeloxifene. Study done by Khan et al observed similar results with a significant reduction in mean endometrial thickness at 6 months after treatment from $11 \mathrm{~mm}$ to $8.4 \mathrm{~mm} .{ }^{15}$ Masand et al observed the mean endometrial thickness in the pretreatment was $8.55 \pm 2.42 \mathrm{~mm}$. There was decrease in mean ET at 1 month $7.57 \pm 2.76 \mathrm{~mm}, 3$ months $5.91 \pm 1.65$ and 6 months $5.41 \pm 1.78 \mathrm{~mm}$ of treatment and the decrease in ET was found to be statistically significant. This study findings were similar to our study. ${ }^{10}$ Study conducted by Ahmed et al, Godha et al, Komaram et al, Dhananjay et al observed similar findings. ${ }^{16-19}$

The mean PBAC score before treatment was $201.40 \pm 30.482$ and it was decreased significantly to $132.23 \pm 40.069$ after 3 months and 102.40 \pm 63.083 after 6 months of treatment with ormeloxifene. Study conducted by Gupta et al observed the mean pretreatment PBAC score was 360 , which was significantly reduced to 209.5 at 2 months, 88.7 at 4 months and 68.2 at 6 months of post treatment similar to our finding. 20 Study conducted by Biswas et al also observed a significant decrease in mean PBAC score from 272.0 to 107.8 at 3 months post treatment $(\mathrm{t}=20.20, \mathrm{p}<0.001) .{ }^{13}$ Gandotra observed a decrease from 316 pretreatment to 52 at 6 months post treatment. $^{12}$ Agarwal observed a decrease from 334 at pretreatment to 32 at 6 months post treatment. ${ }^{11}$ 
Only one case $(3.3 \%)$ had myocardial infarction following drug usage as an adverse effect of ormeloxifene in this study. This finding was much lower as compared to study done by Prerna et al where $42.85 \%$ of cases had side effect of ormeloxifene as white discharge PV, gastric dyspepsia, Vague abdominal Pain, ovrian cyst, headache etc. ${ }^{21}$ In this study, $70 \%$ of the cases were satisfied on treatment with the drug while $30 \%$ of the patients were not satisfied with the drug. Shahad et al observed, $82 \%$ of the cases were satisfied after treatment with ormeloxifene which was comparatively higher than our study. ${ }^{22}$ Study conducted by Mandal et al observed $58.33 \%$ of the cases were highly satisfied $30.56 \%$ cases were satisfied while $11.11 \%$ were poorly satisfied with the treatment. ${ }^{23}$

In this study, there was marked improvement in $86.6 \%$ of cases while $6.7 \%$ cases had no improvement while $6.7 \%$ cases had aggravation of symptoms. Similar results were reported by Bhattacharyya et al, where $81.67 \%$ of the cases had marked improvement, $16.6 \%$ cases had no improvement and $1.67 \%$ cases got worsened after treatment with ormeloxifene. ${ }^{24}$ Study conducted by Agarwal et al observed, $3.33 \%$ cases had no improvement, $8.33 \%$ cases had mild improvement and $88.33 \%$ cases had marked improvement after treatment with ormeloxifene which is almost similar to our study. ${ }^{11}$

\section{Limitations}

The current study was only baseline controlled and the findings need to be confirmed by double-blind placebocontrolled randomized trials. Comparative randomized trials with larger subjects are also required to test this treatment with other medical therapies including combined OCPs, oral progesterone, antifibrinolytics, NSAISDs as well as LNG-IUD.

\section{CONCLUSION}

Ormeloxifene is quick acting (usually bleeding is controlled in 2-3 days), effective and appears to be a promising option for the medical management of DUB. It was found to be an excellent drug in controlling the systems of abnormal uterine bleeding without effecting normal endocrinal and physiological parameters. It leads to a significant reduction in menstrual blood loss, a significant rise in hemoglobin concentration and a significant decrease in endometrial thickness with very minimal side effect. It has a convenient dose schedule of once or twice a week and is cost effective. Further studies with large sample size are needed to throw light regarding the efficacy and safety of the agent.

Funding: No funding sources Conflict of interest: None declared

Ethical approval: The study was approved by the Institutional Ethics Committee

\section{REFERENCES}

1. Bravender T, Emans SJ. Menstrual disorders. ABNORMAL uterine bleeding. Pediatr Clin North Am. 1999;46(3):545-53.

2. Chen BH, Giudice LC. ABNORMAL uterine bleeding. West J Med. 1998;169(5):280-4.

3. Riggs. Selective Estrogen-Receptor ModulatorsMechanisms of Action. 2003;348(12):1-12.

4. Makker A, Tandon I, Goel MM, Singh M, Singh MM. Effect of ormeloxifene, a selective estrogen receptor modulator, on biomarkers of endometrial receptivity and pinopode development and its relation to fertility and infertility in Indian subjects. Fertil Steril. 2009;91(6):2298-307.

5. Shelly W, Draper MW, Krishnan V, Wong M, Jaffe RB. Selective estrogen receptor modulators: an update on recent clinical findings. Obstet Gynecol Surg. 2008;63(3):163-81.

6. Singh MM. Centchroman, a selection estrogen receptor modulator, as a contraceptive and for the management of hormone-related clinical disorders. Med Res Rev. 2001;21(4):302-47.

7. Lal J. Clinical pharmacokinetics and interaction of centchroman - A mini review. Contraception. 2010;81(4):275-80.

8. Fraser IS, Critchley HOD, Broder M, Munro MG. The FIGO recommendations on terminologies and definitions for normal and Abnormal uterine bleeding. Semin Reprod Med. 2011;29(5):383-90.

9. Frick KD, Clark MA, Steinwachs DM, Langenberg P, Stovall D, Munro MG, et al. Financial and Quality-of-Life Burden of ABNORMAL Uterine Bleeding Among Women Agreeing To Obtain Surgical Treatment. Women's Heal Issues. 2009;19(1):70-8.

10. Masand D, Gupta S, Patel J. To Observe Effect of Ormiloxifene in Medical Management of ABNORMAL Uterine Bleeding. J Evol Med Dent Sci. 2015;4(4):587-97.

11. Agarwal N, Singh S. The Efficacy and Safety of Ormeloxifene in ABNORMAL Uterine Bleeding. IOSR J Dent Med Sci. 2013;5(5):18-21.

12. Gandotra N, Sharma $P$. The role of Sevista (ormeloxifene) in the management of ABNORMAL uterine bleeding. Int J Reprod Contraception, Obstet Gynecol. 20137;6(1):219-22.

13. Biswas SC, Saha S, Bag T, Ghosh Roy S, Roy A, Kabiraj S. Ormeloxafene A Selective Estrogen Receptor Modulator, For Treatment of ABNORMAL Menorrhagia. J Obs Gynecol Ind. 2004;54(1):56-9.

14. Talukdar RK, Gharphalia DJ, Mani A. Efficacy of Selective Estrogen Receptor Modulators in the Management of Abnormal Uterine Bleeding In Women of Early Reproductive Age Group. 2016;4:3669-75.

15. Khan SA, Manzoor M, Abdullah A, Banoo A. Efficacy and safety of ormeloxifene in the management of dysfunction uterine bleeding. J Dent Med Sci. 2014;13:39-42. 
16. Ahmed SB, Mogri S, Barala S. Role of ormeloxifene in the management of ABNORMAL uterine bleeding: a prospective study. 2016;5(12):4373-6.

17. Godha Z, Mohsin Z, Hakim S, Wasim S. Comparative Study of Ormeloxifene and Medroxyprogesterone Acetate in Abnormal Uterine Bleeding. J Obstet Gynecol Ind. 2016;66:395-9.

18. Komaram RG, PallaJ CG. A Study of Efficacy of Ormeloxifene in the Pharmacological Management of ABNORMAL Uterine Bleeding. J Clin Diagnostic Res. 2013;7(11):2534-6.

19. Dhananjay BS, Nanda SK. The role of sevista in the management of ABNORMAL uterine bleeding. J Clin Diagnostic Res. 2013;7(1):132-4.

20. Gupta U, Shrivastava K, Katiyar G, Arif A, Gupta NK. Study of Efficacy and Safety of Ormeloxifene in the Management of ABNORMAL Menorrhagia. 2014;2:1-4.

21. Prerna S, Asha V, Kusum V, Richa G, Bhoomika S. Role of Ormeloxifene in Management of Abnormal Uterine Bleeding. 2017;5:796-9.
22. Shahab SF, Jain S, Jain J, Jain U. Ormeloxifene : Boon to perimenopausal ABNORMAL Uterine Bleeding (AUB) women in avoiding hysterectomies. Int J Med Sci Educ. 2014;1(1):17-24.

23. Mandal D, Parmanik S, Surana S, Hazra A, Mandal S, Maity TK. Comparative study of low-dose oral contraceptive pill and ormeloxifene in the treatment of ABNORMAL uterine bleeding. 2014;3(4):225-31.

24. Bhattacharyya TK, Banerji A. Efficacy of a Selective Estrogen Receptor Modulator: " Ormeloxifene " in Management of ABNORMAL Uterine Bleeding. Sou As Fed Obstet Gynecol. 2010;2(3):207-11.

Cite this article as: Varwatte PB, Fonseca M. Fetal Study of the efficacy of ormeloxifene in abnormal uterine bleeding. Int J Reprod Contracept Obstet Gynecol 2020;9:4941-5. 